\title{
PENGARUH KECERDASAN LOGIS MATEMATIS TERHADAP KEMAMPUAN PEMECAHAN MASALAH SISWA KELAS VII SMPN 30 MAKASSAR
}

\author{
Muthmainnah Asmal \\ Program Studi Pendidikan Matematika, Fakultas Keguruan dan Ilmu Pendidikan \\ Universitas Pancasakti Makassar \\ e-mail: muthmainnahasmal@unpacti.ac.id
}

\begin{abstract}
ABSTRAK
Penelitian ini bertujuan untuk mengetahui adakah pengaruh kecerdasan logis matematis terhadap kemampuan pemecahan masalah matematika. Penelitian ini menggunakan pendekatan kuantitatif dengan metode korelasional. Variabel penelitian terdiri dari variable bebas yaitu kecerdasan logis matematis dan variable terikatnya adalah kemampuan pemecahan masalah matematika. Populasi penelitian adalah seluruh peserta didik kelas VII SMPN 30 Makassar Tahun Pelajaran 2019/2020 yang berjumlah 105 orang siswa. Sampel diambil menggunakan simple random sampling sebanyak 55 orang siswa sebagai responden. Teknik pengumpulan data menggunakan tes dengan instrument berupa tes yang terdiri atas 25 butir soal pilihan ganda untuk mengukur tingkat kecerdasan logis matematis dan untuk tes mengukur kemampuan pemecahan masalah sebanyak 8 butir soal essay. Teknik analisis data yang digunakan adalah analisis regresi sederhana. Berdasarkan hasil analisis data menggunakan analisis regresi diperoleh nilai Fhitung $=0,433$ dan $F_{\text {tabel }}(5 \%)=0,297$, karena $F_{\text {hitung }} \geq F_{\text {tabel, }}$ maka $\mathrm{H}_{0}$ ditolak Ini berarti terdapat pengaruh yang positif dan signifikan kecerdasan logis matematis terhadap kemampuan pemecahan masalah siswa kelas VII SMPN 30 Makassar. Adapun besarnya pengaruh kecerdasan logis matematis terhadap kemampuan pemecahan masalah siswa adalah sebesar $18,75 \%$.
\end{abstract}

Kata Kunci :Kecerdasan logis matematis, Kemampuan pemecahan masalah

\section{ABSTRACT}

The purpose of this study was to examine analyze the presence or absence of the influence mathematical logical intelligence on problem solving abilities. The approach used in this study is quantitative approach with correlational methods. The independent variable is mathematical logical intelligence and the dependent variable is mathematical problem solving abilities. The population was class VII of SMPN 30 Makassar academic year 2019/2020. Samples were taken using simple random sampling of 55 students as respondents. The instruments in this study used multiple choice questions which numbered 25 questions to measure mathematical logical intelligence and 8 essay questions to measure problem solving abilities. Data analysis technique used is simple regression analysis. Based on the results of data analysis using regression analysis, the value of $F_{\text {count }}=0.433$ and $F_{\text {table }}(5 \%)=0.297$, because $F_{\text {count }} \geq F_{\text {table }}$, then $H_{0}$ is rejected. This means that there is a positive and significant effect ofmathematical logical intelligence towards problem solving abilities of class VII students of SMPN 30 Makassar. The magnitude of the influence of mathematical logical intelligence on students' problem solving abilities is $18.75 \%$.

Keywords: Mathematical logical intelligence, problem solving ability 


\section{PENDAHULUAN}

Salah satu modal utama dalam proses pembelajaran adalah kecerdasan. Kecerdasan merupakan kemampuan dalam memahami sesuatu dan kemampuan dalam memberikan pendapat (Mustaqim, 2004). Gardner dalam Irvaniyah dan Oktaviana (2014) merumuskan sembilan jenis kecerdasan, diantaranya kecerdasan verballinguistik, kinestetik, music, logismatematis, visual-spasial interpersonal, intrapersonal, naturalis; dan eksistensialis. Kecerdasan logis matematis merupakan salah satu kecerdasan yang menunjang proses pembelajaran matematika. Karakterisik kecerdasan logis matematis ditandai dengan kemampuan seseorang dalam berenalar, berfikir logis, mengolah angka, membuat pola hubungan, memahami keteraturan pola, kemampuan berhitung, dan kemampuan untuk memecahkan masalah (Indragiri,2010).

Setiap anak memiliki kecerdasan yang berbeda-beda, begitupun dengan kecerdasan matematis logis ini.Hal ini membuat setiap anak memiliki kemampuan belajar yang berbedabeda sehingga dapat berpengaruh dalam kemampuan pemecahan masalah matematika. Siswa dengan kecerdasan matematis logis yang tinggi cenderung berpikir secara konseptual, misalnya menyusun hipotesis, mengadakan kategorisasi dan klasifikasi terhadap apa yang dihadapinya serta menyenangi kegiatan menganalisis dan mempelajari sebab-akibat terjadinya sesuatu (Nurdin dan Yaumi, 2013). Adapun Baharuddin (2007) mendefinisikan kecerdasan logis matematis sebagai kecerdasan yang berkaitan dengan kemampuan penggunaan bilangan dan logika secara efektif, senada dengan defenisi kecerdasan logis matematis menurut Jayantika (2013) merupakan kemampuan seseorang untuk menganalisar secara logis untuk memecahkan kasus atau permasalahan dan melakukan perhitungan secara matematis.

Menurut Masykur dan Fathani (2007) untuk mengetahui kecerdasan matematis logis anak dapat dilihat dalam indicator berikut:

1) Menyukai aktivitas yang melibatkan angka, urutan, pengukuran, dan dapat mengerti pola hubungan;

2) Mampu memikirkan dan menyusun solusi dengan urutan logis;

3) Mampu melakukan proses berpikir deduktifdan induktif.

4) Suka mencari penyelesaian suatu masalah dan perkiraan;

5) Menunjukkan minat yang besar terhadap analogi dan silogisme;

Kegiatan pembelajaran matematika tidak akan lepas dari kemampuan pemecahan masalah matematika. Seperti yang telah tercantum dalam Undang-Undang tentang StandarIsi Pendidikan Dasar dan Menengah, Tahun 2016 yaitu: "Kompetensi pada muatan matematika adalah menunjukkan sikap positif ber matematika, yaitu: logis, cermat, teliti, jujur, bertanggung jawab, dan tidak mudah menyerah dalam menyelesaikan masalah,sebagai wujud implementasi kebiasaan dalam inkuiri dan eksplorasi matematika, memiliki rasa ingin tahu dan semangat belajar yang kontinu, percaya diri, dan ketertarikan pada matematika yang terbentuk melalui pengalaman belajar" Kemampuan pemecahan masalah merupakan komponen penting pada pembelajaran matematika karena sangat dibutuhkan dalam penerapan dan pengintegrasian konsep matematika serta dalam pengambilan keputusan. Pemecahan masalah adalah usaha atau cara dalam mencari jalan keluar dari suatu kesulitan (Polya,1973). Sedangkan menurut Saad \& Ghani (2008) pemecahan masalah merupakan proses terencana yang sangat perlu untuk dilaksanakan agar didapatkan penyelesaian tertentu dari sebuah permasalahan yang mungkin tidak diperoleh segera.

Pada pemecahan masalah matematika siswa harus memahami pertanyaan dengan baik dan memahami konsep sesuai masalah yg diberikan, sehingga menurut Gardner (Irvaniyah dan 
Oktaviana, 2014) kecerdasan logis matematis yang dimiliki siswa sangat diperlukan dalam menyelesaikan masalah matematika karena merupakan kemampuan seseorang dalam berpikir secara induktif dan deduktif, berpikir menurut logika memahami dan menganalisis pola, serta memecahkan masalah.

"Ketika memecahkan masalah matematika siswa harus memahami terlebih dahulu permasalahan yang dihadapi, membutuhkan pemahaman, analisis, perhitungan, dan imajinasi yang baik. Siswa juga harus memahami keterkaitan antar informasi yang ada pada masalah sehingga gambaran dari penyelesaian masalah dapat diketahui. Kemampuan tersebut dapat dilakukan dengan baik oleh orang yang memiliki kecerdasan logis matematis" (Zulkarnain dan Nurbiati,2019)

Berdasarkan pemaparan diatas sangat memungkinkan bahwa peserta didik yang memiliki kecerdasan logis matematis yang tinggi memiliki kemampuan pemecahan masalah yang tinggi pula tidak terkecuali pada siswa kelas VII SMPN 30 Makassar. Sehingga jika kecerdasan logis matematis dikaitkan dengan kemampuan pemecahan masalah dapat diidentifikasikan bahwa hal tersebut ada pengaruhnya. Berdasarkan hal tersebut penulis berminat mengadakan penelitian yang secara khusus untuk mengetahui adakah pengaruh kecerdasan logis matematis terhadap kemampuan pemecahan masalah matematika pada siswa kelas VII SMPN 30 Makassar

\section{METODE PENELITIAN}

Penelitian ini menggunakan pendekatan kuantitatif dengan metode korelasional, dengan tujuan untuk mengetahui hubungan antar variabel, yaitu hubungan antara kecerdasan matematis logis dengan kemampuan pemecahan masalah. Pada penelitian ini kecerdasan matematis logis merupakan variable bebas dan kemampuan pemecahan merupakan variabel terikat. Populasi penelitian adalah seluruh peserta didik kelas VII SMPN 30 Makassar Tahun Pelajaran 2019/2020 yang berjumlah 105 orang siswa. Sampel diambil menggunakan simple random sampling sebanyak 55 orang siswa sebagai responden. Untuk memperoleh data kecerdasan logis matematis dan kemampuan pemecahan masalah digunakan instrument berupa tes, sebanyak 25 butir soal pilihan ganda kecerdasan logis matematis dan untuk tes kemampuan pemecahan masalah sebanyak 8 butir soal essay. Berdasarkan aspek-aspek yang dapat diukur dalam tes dapat ditarik indikator sebagai berikut

\section{Tabel 1.Indikator kecerdasan logis matematis dan Kemampuan pemecahan masalah}

\begin{tabular}{|c|c|c|}
\hline Variabel & Indikator & Sub Indikator \\
\hline \multirow{11}{*}{$\begin{array}{c}\text { Kecerdasan } \\
\text { Matematis } \\
\text { Logis }\end{array}$} & $\begin{array}{l}\text { Kemampuan } \\
\text { berhitung }\end{array}$ & $\begin{array}{l}\text { a. Menentukan hasil operasi hitung } \\
\text { matematika }\end{array}$ \\
\hline & \multirow[t]{6}{*}{ Kemampuan bernalar } & a.Mengajukan dugaan \\
\hline & & b.Manipulasi matematika \\
\hline & & c. Mengajukan simpulan,bukti,alasan \\
\hline & & d. Kesahihan argument \\
\hline & & e.Mengetahui pola dari gejala \\
\hline & & $\begin{array}{l}\text { metematika untuk membuat } \\
\text { generalisasi }\end{array}$ \\
\hline & \multirow[t]{4}{*}{ Berpikir logis } & a. Mengingat \\
\hline & & b.Membandingkan \\
\hline & & c. Menganalisis \\
\hline & & d.menyimpulkan \\
\hline
\end{tabular}




\begin{tabular}{|c|c|c|}
\hline & Problem Solving & $\begin{array}{l}\text { a.memahami masalah } \\
\text { b.membuat rencana penyelesaian } \\
\text { c. melaksanakan rencana penyelesaian } \\
\text { d.memeriksa kembali, }\end{array}$ \\
\hline \multirow{4}{*}{$\begin{array}{l}\text { Kemampuan } \\
\text { Pemecahan } \\
\text { Masalah }\end{array}$} & Memahami masalah & $\begin{array}{l}\text { a.menentukan syarat cukup dan } \\
\text { syarat perlu }\end{array}$ \\
\hline & Membuat rencana & $\begin{array}{l}\text { a.mengemukakan langkah-langkah } \\
\text { yang akadigunakan untuk } \\
\text { memecahkan masalah } \\
\text { b.menemukan keterkaitn antara } \\
\text { syarat cukup dan syarat perlu }\end{array}$ \\
\hline & $\begin{array}{l}\text { Melaksanakan } \\
\text { Rrencana }\end{array}$ & $\begin{array}{l}\text { a. menggunakan langkah-langkah } \\
\text { secara benar } \\
\text { b.terampil dalam algoritma dan } \\
\text { ketepatan menjawab soal }\end{array}$ \\
\hline & Memeriksa Kembali & $\begin{array}{l}\text { a. menggunakan informasi yang ada } \\
\text { untuk mengerjakan kembali soal } \\
\text { dengan cara yang berbeda }\end{array}$ \\
\hline
\end{tabular}

Pengujian hipotesis statistik dalam penelitian ini menggunakan analisis regresi sederhana. Analisis regresi sederhana merupakan analisis yang digunakan untuk mengetahui pengaruh variabel bebas terhadap variabel terikat dengan kata lain untuk membuktikan bahwa terdapat atau tidak terdapatnya hubungan fungsional antara variabel bebas dengan variabel terikatnya (Usman \& Akbar, 2008:). Persamaan regresi sederhana dengan satu prediktor dapat dibuat persamaan sebagai berikut (Sugiyono,2012):

$$
\widehat{Y}=a+b X
$$

Keterangan:

$\mathrm{Y}=$ subjek dalam variabel dependen yang diprediksikan

$\mathrm{a}$ = harga $\mathrm{Y}$ ketika harga $\mathrm{X}=0$

$\mathrm{b}=$ angka arah atau koefisien regresi, yang menunjukkan angka peningkatan ataupun penurunan variabel dependen yang didasarkan pada perubahan variabel independen. Bila $(+)$ arah garis naik, bila (-) arah garis turun.

$\mathrm{X}=$ subjek pada variabel independen yang mempunyai nilai tertentu.

Dimana keofisien a dan $\mathrm{b}$ dapat diperoleh dengan rumus:

$$
\begin{gathered}
a=\frac{(\Sigma Y)\left(\Sigma X^{2}\right)-(\Sigma X)(\Sigma X Y)}{n \cdot \Sigma X^{2}-(\Sigma X)^{2}} \\
b=\frac{n \cdot \sum X Y-\left(\sum X\right)\left(\sum X Y\right)}{n \cdot \sum X^{2}-\left(\sum X\right)^{2}}=\frac{\sum X Y}{\sum X^{2}}
\end{gathered}
$$

Untuk menguji hubungan antara $X$ dan $Y$ digunakan rumus (Sugiyono, 2012):

$$
r=\frac{n \sum X Y-\sum X \sum Y}{\sqrt{\left.n \sum X^{2}-\left(\sum X\right)^{2}\right)\left(n \sum Y^{2}-\left(\sum Y\right)^{2}\right.}}
$$

Hipotesis yang diuji adalah :

$\mathrm{H}_{0}: \mathrm{r}_{\text {hitung }}<\mathrm{r}_{\text {tabel; }}$ tidak terdapat hubungan yang positif dan signifikan antara kecerdasan logis matematis dan kemampuan pemecahan masalah matematika.

$\mathrm{H}_{0}: \mathrm{r}_{\text {hitung }}>\mathrm{r}_{\text {tabel; }}$ terdapat hubungan yang positif dan signifikan antara kecerdasan logis matematis dan kemampuan pemecahan masalah matematika 
Selanjutnya membandingkan nilai koefisien korelasi dengan tabel interpretasi untuk melihat seberapa kuat korelasi antara variable kecerdasan logis matematis dan variable kemampuan pemecahan masalah:

Tabel 2. Pedoman Untuk Memberikan Interpretasi Koefisien Korelasi

\begin{tabular}{l|l} 
Interval koefisien & Tingkat hubungan \\
\hline $0,000-0,199$ & Sangatrendah \\
$0,200-0,399$ & Rendah \\
$0,400-0,599$ & Sedang \\
$0,600-0,799$ & Kuat \\
$0,800-1,000$ & Sangat kuat \\
\hline
\end{tabular}

(Sumber : Sugiyono,2012)

Untuk mencari besarnya pengaruh variabel kecerdasan matematis logis terhadap variable kemampuan pemecahan masalah digunakan koefisien determinasi.Rumus koefisien determinasi adalah sebagai berikut (sugiyono,2012):

$$
K D=r^{2} \times 100 \%
$$

\section{HASIL PENELITIAN DAN PEMBAHASAN}

Sebagai syarat agar dapat dilakukan analisis regresi linier sederana, terlebih dahulu dilakukan uji linieritas dan keberartian. Hasil uji linieritas yang diperoleh $\mathrm{F}_{\text {hitung }}=0,96<\mathrm{F}_{\text {tabel }}=$ 2,05 dengan taraf signifikansi 5\%. Dan untuk uji keberartian diperoleh $F_{\text {hitung }}=9,07>F_{\text {tabel }}=4,07$ dengan taraf signifikansi 5\%. Disimpulkan bahwa regresi $\mathrm{Y}$ atas $\mathrm{X}$ linier dan koefisien arah regresi berarti, Sehingga memenuhi syarat untuk uji regresi linier.

Hasil analisis regresi diperoleh persamaan regresi $\widehat{\boldsymbol{Y}}=\mathbf{3 6 . 5 5 0}+\mathbf{0}, \mathbf{3 9 9 X}$, ini berarti bahwa jika kecerdasan logis matematis bernilai 0 maka kemampuan pemecahan masalah matematika sebesar 36,550 poin sedangkan jika kecerdasan logis matematis naik sebesar 1 poin maka kemampuan pemecahan masalah matematika naik sebesar 0,399 poin. Dari persamaan regresi $\widehat{\boldsymbol{Y}}=\mathbf{3 6 . 5 5 0}+\mathbf{0}, \mathbf{3 9 9 X}$ terlihat bahwa koefisien b bernilai positif, ini menunjukkan perubahan $Y$ searah dengan perubahan X. Jadi nilai Y akan meningkat jika nilai X meningkat, dan begitupun sebaliknya. Jadi disimpulkan bahwa kemampuan pemecahan masalah siswa berbanding lurus dengan kecerdasan logis matematis.

Hasil pengujian hubungan antara kecerdasan logis matematis dan kemampuan pemecahan masalah diperoleh $r_{\text {hitung }}=0,4333>r_{\text {tabel }}=0,297$, Dari hasil analisis tersebut dapat dikemukakan bahwa hipotesis dalam penelitian ini yaitu "ada pengaruh yang positif dan signifikan kecerdasan logis matematis terhadap kemampuan pemecahan masalah siswa kelas VII SMPN 30 Makassar" dapat diterima. Besarnya pengaruh variabel kecerdasan logis matematis terhadap kemampuan atau koefisien determinasinya yaitu $0,4333^{2}$ x $100 \%=18,75 \%$. Hal ini berarti bahwa kecerdasan logis matematis berpengaruh terhadap kemampuan pemecahan masalah siswa sebesar $18.75 \%$, sedangkan sisanya ditentukan oleh faktor lain.

Hasil penelitian menunjukkan adanya pengaruhkecerdasan logis matematis terhadap kemampuan pemecahan masalah siswa, hal inidengan pendapat Lwin (2008) bahwa orang yang memiliki kecerdasan logis matematis yang tinggi juga memiliki kemampuan lebih dalam menangani bilangan dan perhitungan, pola, pemikiran logis dan ilmiah sehingga lebih mudah dalam memecahkan masalah matematika, 
Nurdin dan Yaumi (2013) menyatakan "kecerdasan matematika disebut juga kecerdasan logis dan penalaran karena merupakan dasar dalam memecahkan masalah dengan memahami prinsip-prinsip yang mendasari sistem kausal atau dapat memanipulasi bilangan, kuantitas dan operasi" Hal tersebut mengindikasikan bahwa kecerdasan logismatematis memiliki hubungan yang erat dengan kemampuan pemecahan masalah matematika.

\section{KESIMPULAN}

Berdasarkan hasil pengolahan data, pembahasan serta tujuan daripenelitian ini, dapat disimpulkan ada pengaruh yang positif dan signifikan kecerdasan logis matematis terhadap kemampuan pemecahan masalah siswa kelas VII SMPN 30 Makassar. Hal ini dibuktikan dengan uji hipotesis statistik menggunakan analisis regresi diperoleh nilaiFhitung $=0,433$ dan Ftabel(5\%) $=0$,297 sehingga diambil keputusan bahwa $\mathrm{H0}$ ditolak, karena $\mathrm{F}_{\text {hitung }} \geq \mathrm{F}_{\text {tabel }}$, dan kecerdasan logis matematis memberikan kontribusi terhadap kemampuan pemecahan masalah siswa sebesar $18,75 \%$.

\section{SARAN}

Berdasarkan penelitian yang telah dilakukan, beberapa saran yang peneliti ajukan antara lain:

1. Bagi guru; dengan adanya pengaruh kecerdasan logis matematis terhadap kemampuan pemecahan masalah, guru diharapkan mampu meningkatkan kecerdasan logis matematis dalam pembelajaran di kelas guna meningkatkan kemampuan pemecahan masalah siswa.

2. Bagi siswa; dengan pengaruh kecerdasan logis matematis terhadap kemampuan pemecahan masalah, siswa seharusnya melakukan beberapa kebiasaan yang dapat meningkatkan kecerdasan logis matematis.

3. Bagi peneliti dan penelitian selanjutnya; diharapkan mampu melakukan penelitian lanjutan terkait faktor-faktor lain yang memengaruhi kemampuan pemecahan masalah siswa sehingga akan dapat memaksimalkan langkah dalam mengembangkan kemampuan pemecahan masalah siswa.

\section{REFERENSI}

Akbar P.S dan Usman. 2008. Pengantar Statistika, Jakarta : Bumi Aksara.

Baharudin. 2007.Teori Belajar dan Pembelajaran. Jogjakarta: Ar-Ruzz Media.

Indragiri, 2010. Kecerdasan Optimal: Cara Ampuh Memaksimalkan Kecerdasan Anak,Jogjakarta: Starbooks.

Irvaniyah, Iyan, Reza Oktaviana Akbar. 2014. Analisis Kecerdasan Logis Matematis dan Kecerdasan Linguistik Siswa Berdasarkan Jenis Kelamin. Dalam Jurnal EduMa,Vol. 3 No.1, ISSN $2086-3918$.

Lwin, May, dkk. 2008. Cara Mengembangkan Berbagai Komponen Kecerdasan: Petunjuk Praktis bagi Orang Tua yang Mempunyai Anak Tujuh Tahun atau Kurang, terj.Christine Sujana,Jakarta: PT Indeks.

Muhammad Yaumi,Nurdin Ibrahim. 2013. Pembelajaran Berbasis Kecerdasan Jamak (Multiple Intelligences): Mengidentifikasi dan Mengembangkan Multitalenta Anak,Jakarta: Kencana Prenadamedia Group.

Masykur, M., \& Fathani, d. A. 2009.Mathematical Intelligence.edited by A. Safa.Yogyakarta: ArRuzz Media. 
Mustaqim. 2004. Psikologi Pendidikan. Semarang: Fakultas Tarbiyah IAIN Walisongo.

Polya, G. 1973. How to Solve it. New Jersey: Princeton University Press.

Saad, N. S. \& S. A. Ghani. 2008. Teaching Mathematics in Secondary School: Theories and Practices. Perak: Universiti Pendidikan Sultan Idris.

Sugiyono. 2012. Metode Penelitian Kuantitatif, Kualitatif dan R\&D. Bandung: Afabeta

Undang-Undang tentang Standar Isi Pendidikan Dasar dan Menengah, Tahun 2016.

Zulkarnain, Ihwan \& Nurbiati, Ika.2019. Pengaruh Kecerdasan Logis Matematis terhadap Kemampuan Pemecahan Masalah.Prosiding DPNPM Unindra 2019.ISSN 2581-0812. 